\title{
STUDI TENTANG SIKAP KEWIRAUSAHAAN BERDASARKAN PRESTASI AKADEMIK MAHASISWA DPTM PRODI S-1 FPTK UPI
}

\author{
Amriansyah Alfia ${ }^{1}$, Inu H. Kusumah ${ }^{2}$, Sulaeman $^{3}$ \\ Universitas Pendidikan Indonesia \\ Jl. Dr. Setiabudhi No. 229 Bandung 40154 \\ amriansyah93@gmail.com
}

\begin{abstract}
ABSTRAK
Penelitian ini dilatarbelakangi oleh sulitnya lulusan perguruan tinggi dalam mencari pekerjaan. Penelitian ini bertujuan untuk mengetahui gambaran sikap kewirausahaan yang dimiliki mahasiswa DPTM Prodi S-1 FPTK UPI Angkatan 2013 berdasarkan prestasi akademik yang diharapkan dapat menjadi solusi dari permasalahan sulitnya mencari pekerjaan bagi lulusan perguruan tinggi. Metode yang digunakan dalam penelitian ini adalah metode deskriptif kuantitatif. Sampel pada penelitian ini dipilih secara random. Data hasil penelitian didapat dari angket. Hasil penelitian menunjukkan bahwa sikap kewirausahaan mahasiswa DPTM Prodi S-1 FPTK UPI Angkatan 2013 sebagian besar berada pada kategori tinggi dan memiliki IPK dengan predikat sangat memuaskan. Hal ini dikarenakan sebagian besar responden memiliki nilai tinggi pada tiga aspek penting komponen sikap kewirausahaan yaitu kognitif, afektif, dan psikomotor. Selain itu tingginya sikap kewirausahaan yang dimiliki responden juga dikarenakan tingginya tingkat kesadaran responden terhadap manfaat berwirausaha.
\end{abstract}

Kata kunci: sikap kewirausahaan, prestasi, teknik mesin.

\section{PENDAHULUAN}

Dunia kerja saat ini sangat kompetitif dalam menyeleksi calon pegawainya. Bukan hanya gelar, diperlukan juga prestasi akademik yang sesuai standar penerimaan calon pegawai, diantaranya akreditasi jurusan yang minimal B. Ada yang lebih mengutamakan lulusan yang memiliki pengalaman, dan mensyaratkan memiliki IPK (Indeks Prestasi Kumulatif) dengan standar tertentu. Hal ini membuat calon lulusan perguruan tinggi berlomba-lomba untuk mendapatkan prestasi akademik yang cemerlang tanpa kompetensi yang memadai dalam melamar pekerjaan.

Badan Pusat Statistik melaporkan Tingkat Pengangguran Terbuka (TPT) pada Februari 2016 menjadi 5,50\% dengan jumlah 7,02 juta orang menurun 430 ribu orang atau 7,45 juta orang dengan TPT 5,81 \% pada Februari 2015. Namun sangat disayangkan tingkat pengangguran pada jenjang SMK dan Universitas selama setahun terakhir naik masing-masing 9,84\% dan 6,22\%. Kenaikan jumlah pengangguran ini disebabkan oleh penyerapan tenaga kerja yang tidak sebanding dengan jumlah lulusan perguruan tinggi. Hal ini pun memicu permasalahan baru, jika sedikit yang bekerja, maka angka kemiskinan

\footnotetext{
${ }^{1}$ Mahasiswa Departemen Pendidikan Teknik Mesin FPTK, UPI

${ }^{2}$ Dosen Departemen Pendidikan Teknik Mesin FPTK, UPI

${ }^{3}$ Dosen Departemen Pendidikan Teknik Mesin FPTK, UPI
} 
akan meningkat yang kemudian menimbulkan permasalahan lainnya seperti kriminalitas, premanisme, prostitusi dan lain sebagainya. Hal tersebut mendorong lulusan perguruan tinggi berpikir inovatif dalam mencari alternatif pekerjaan (Susita, 2013). Jika mereka tidak kunjung mendapatkan pekerjaan yang diinginkan, maka mereka dapat menciptakan lapangan pekerjaan baru, salah satunya dengan berwirausaha.

Namun faktanya dilapangan hanya beberapa persen lulusan perguruan tinggi berminat untuk berwirausaha. Minat berwirausaha para lulusan lembaga pendidikan rendah (Sufika, 2014). Untuk lulusan SMA, sebesar 22,63\%., sedangkan lulusan perguruan tinggi, lebih rendah lagi, yaitu $6,14 \%$. Rendahnya minat lulusan perguruan tinggi merupakan dampak dari minimnya pengetahuan tentang kewirausahaan serta kurangnya semangat berwirausaha (Hasanah, 2015). Berbagai penyebab yang melatarbelakangi seseorang untuk berwirausaha, seperti terbatasnya modal, takut mengalami kegagalan, serta tidak memiliki sikap kewirausahaan dan lain sebagainya.

Memiliki sikap kewirausahaan pada umumnya merupakan hal penting untuk dimiliki setiap orang dalam mengawali semangat berwirausaha. Sikap kewirausahaan adalah cermin aktivitas wirausahawan (Ani, R2013). Oleh karena itu, lulusan perguruan tinggi wajib memiliki sikap kewirausahaan sebagai modal dasar dalam berwirausaha. Berwirausaha memiliki banyak keuntungan salah satunya dapat menciptakan lapangan pekerjaan baru, selain itu juga berwirausaha dapat menjadikan kita pemimpin dalam perusahaan kita sendiri bukan hanya sebagai pekerja atau pegawai (Prawirokusumo, 2010). Berkaitan dengan hal tersebut, wirausaha ibarat suatu solusi pemecah masalah bagi para lulusan perguruan tinggi dari pengangguran dan kemiskinan. Pelaksanaan wirausaha dijelaskan bahwa untuk memperkenalkan barang dan jasa yang baru, perlu mendobrak sistem ekonomi yang ada, dalam artian berani keluar jalur menciptakan organisasi baru untuk membuka peluang pekerjaan baru (Dewi, 2015). Melakukan wirausaha tentu saja terlebih dahulu harus menanamkan di dalam diri tentang sifat dan nilai-nilai yang bermutu tinggi sebelum terjun diranah berwirausaha. Terdapat tiga poin penting yang tidak dapat dipisahkan dalam pribadi yang bermutu tinggi yaitu: sikap mental berwirausaha, kewaspadaan mental berwirausaha dan keahlian dan ketrampilan berwirausaha (Alma, 2009).

\section{METODE PENELITIAN}

Penelitian ini menggunakan metode penelitian deskriptif kuantitatif. Data diperoleh dari sampel populasi penelitian dianalisis sesuai dengan metode statistik yang 
digunakan. Fokus penelitian yaitu pada sikap kewirausahaan di Departemen Pendidian Tehnik Mesin (DPTM) Fakultas Pendidikan Tehnik Kejuruan (FPTK) Universitas Pendidikan Indonesia (UPI) Bandung Program studi S-1, angkatan 2013, dimana terdapat 3 konsentrasi yaitu otomotif, produksi perancangan dan refrigasi tata udara. Jumlah subyek keseluruhan 101 yang terdiri dari konsentrasi otomotif yang berjumlah 56 orang, produksi perancangan 30 orang dan refrigasi tata udara 15 orang.

Data penelitian ini diperoleh dari angket, dokumentasi, dan studi litelatur. Penelitian diawali dengan studi litelatur tentang sikap kewirausahaan mahasiswa DPTM FPTK UPI. Pembuatan instrumen dan uji coba instrumen, setelah itu penyebaran angket sikap kewirausahaan dan dokumentasi prestasi akademik mahasiswa DPTM FPTK UPI kemudian dilakukan pengolahan data lalu menghasilkan kesimpulan dan rekomendasi.

\section{HASIL PENELITIAN}

Hasil penelitian terkait sikap kewirausahaan mahasiswa telah dirangkum pada Gambar 1.

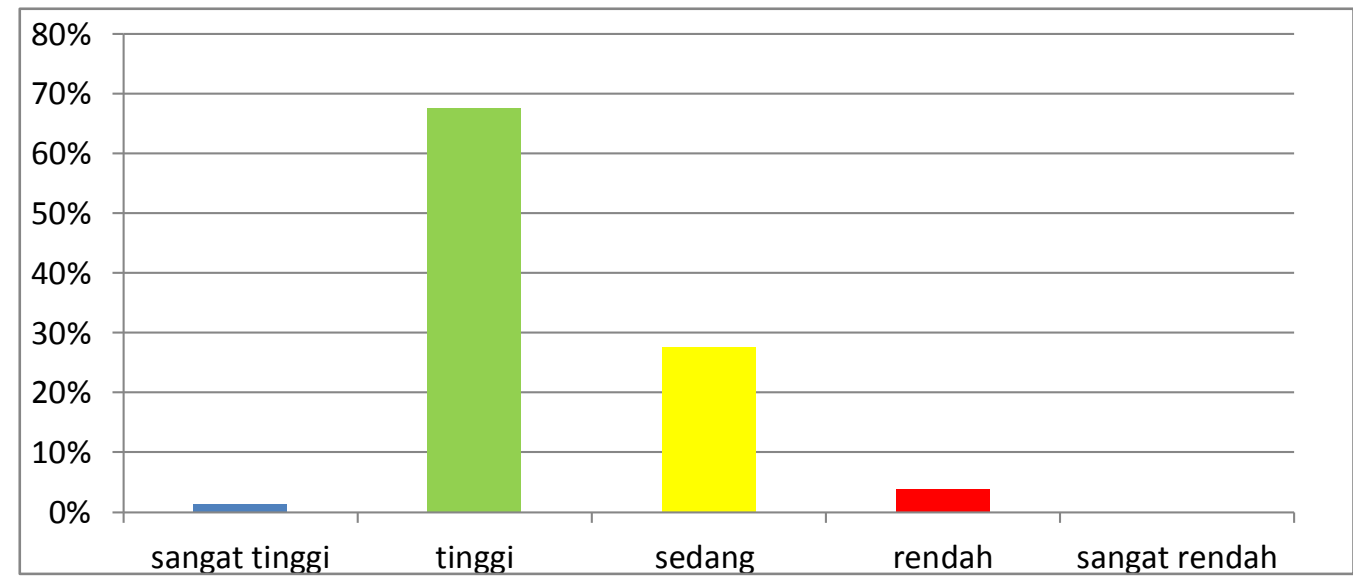

Gambar 1. Grafik Sikap Kewirausahaan (Rentan Skor)

Prestasi akademik yang dinyatakan dalam bentuk IPK, yang telah diisi sebanyak 80 responden mahasiswa DPTM Prodi S-1 FPTK UPI diinterpretasikan dalam Tabel 1.

Tabel 1. Data Prestasi Akademik IPK

\begin{tabular}{ccc}
\hline Rentang & Frekuensi & Prosentase \\
\hline $3,51-4,00$ & 2 & $3 \%$ \\
$3,01-3,50$ & 60 & $75.00 \%$ \\
$2,76-3,00$ & 18 & $22.50 \%$ \\
Jumlah & 80 & $100 \%$ \\
\hline
\end{tabular}


Tabel 2. Sikap Kewirausahaan Berdasarkan Prestasi

\begin{tabular}{cccccc}
\hline \multirow{2}{*}{ Rentang IPK } & \multicolumn{5}{c}{ Kategori Sikap Kewirausahaan } \\
\cline { 2 - 6 } & Sangat tinggi & Tinggi & Sedang & Rendah & Sangat Rendah \\
\hline $3,51-4,00$ & 1 & 1 & 0 & 0 & 0 \\
$3,01-3,50$ & 11 & 40 & 7 & 2 & 0 \\
$2,76-3,00$ & 3 & 9 & 6 & 6 & 0 \\
\hline
\end{tabular}

\section{PEMBAHASAN}

Subjek penelitian ini adalah mahasiswa program studi S-1, Departemen Pendidikan Teknik Mesin, Fakultas Pendidikan Teknik Kejuruan UPI angkatan 2013, konsentrasi otomotif, produksi prencangan dan refrigasi tata udara. Pengambilan data dilakukan dengan cara menyebar instrumen kepada sampel yang telah dipilih secara random melalui ketua mahasiswa tiap konsentrasi kelas dari mulai tanggal 29 November 2016 sampai tanggal 9 Desember 2016. Proses pencarian data penelitian menggunakan angket yang terdiri dari 44 item pernyataan kepada 80 sampel. Gambaran mengenai sikap kewirausahaan mahasiswa DPTM Prodi S-1 FPTK UPI konsentrasi otomotif, produksi perancangan dan refrigasi tata udara ada pada Gambar 1.

Sebanyak satu mahasiswa masuk kedalam kategori sangat tinggi dengan skor tertinggi 198. Mahasiswa yang masuk dalam kategori skor tinggi sebanyak 54 orang, mahasiswa yang masuk kedalam kategori sedang sebanyak 22 orang, 3 orang mahasiswa yang memiliki kategori skor rendah. Sedangkan tidak ada mahasiswa yang termasuk kategori sangat rendah.

Data menunjukkan bahwa IPK dengan rentang 3,01-3,50 berada pada frekuensi yang paling tinggi yaitu 60 orang, sedangkan untuk rentang 2,76-3,00 adalah 18 orang responden diikuti dengan rentang 3,51-4,00 yang paling sedikit yaitu 2 orang responden (Tabel 1). Sikap kewirausahaan berdasarkan prestasi akademik (Tabel 2) mahasiswa DPTM Prodi S-1 FPTK UPI dengan IPK rentang 3,51- 4,00 memiliki sikap kewirausahaan dengan kategori satu orang sangat tinggi dan satu orang dengan kategori tinggi. Mahasiswa rentang 3,01 - 3,50 memiliki sikap kewirausahaan dengan kategori sangat tinggi 11 orang. Mahasiswa yang memiliki kategori tinggi 40 orang dan kategori rendah 7 orang serta 2 orang pada kategori rendah. Untuk mahasiswa yang memiliki rentang IPK 2,76 - 3,00 tiga orang memiliki sikap kewirausahaan pada kategori sangat tinggi. Ada 9 orang mahasiswa yang memiliki sikap kewirausahaan kategori tinggi. Ada orang mahasiswa memiliki sikap 
kewirausahaan kategori sedang dan 6 orang lainnya memiliki sikap kewirausahaan pada ketegori rendah.

Kecenderungan sikap yang tinggi yang dimiliki mahasiswa DPTM Prodi S-1 FPTK UPI dikarenakan terpenuhinya 3 aspek penting dalam pembentukan sikap, yaitu kognitif, afektif dan konatif (Azwar, 1997). Komponen kognitif merupakan respresentasi apa yang dipercayai oleh individu pemilik sikap mengenai penanganan (opini) atau menyangkut masalah isu atau problem yang dikaitkan dalam indikator kisi-kisi instrumen menyangkut tentang pemahaman dan pengetahuan responden terhadap wirausaha. Komponen afektif merupakan perasaan yang menyangkut aspek emosional atau perasaan yang dimiliki seseorang terhadap diri sendiri yang didalam indikator dikaitkan dengan materi tentang kejujuran, kedisiplinan, kreatifitas dan inovasi serta jiwa kepimimpinan (Jain, 2014). Lalu komponen konatif merupakan aspek kecenderungan berprilaku sesuai dengan sikap yang dimiliki seseorang dengan cara-cara tertentu atau dicerminkan dalam bentuk tendensi perilaku, dalam indikator kisi-kisi yaitu sikap kewirausahaan tentang kemandirian, berpikir kedepan dalam bertindak dan berprilaku serta keberanian dalam mengambil resiko.

Hasil penelitian menunjukkan bahwa sebagian besar mahasiswa DPTM Prodi S-1 FPTK UPI memiliki sikap kewirausahaan dengan kategori tinggi. Sebagian besar memiliki rentang IPK yang berada pada 3,01 - 3,50 yang menunjukkan bahwa prestasi akademik responden tergolong sangat memuaskan. Walaupun ada sebagian mahasiswa yang memiliki sikap kewirausahaan pada ketegori sangat tinggi, sedang, rendah dan IPK dibawah rentang 3,01. Mahasiswa yang memiliki sikap kewirausahaan yang tinggi juga memiliki prestasi akademik yang baik (Mutmainah, 2014). Hal ini mencerminkan suatu generasi penerus bangsa yang berpotensi untuk menjadi tonggak peradapan bangsa Indonesia, bukan hanya memiliki sikap yang baik juga memiliki intelektualitas yang tinggi.

\section{KESIMPULAN}

Kesimpulan penelitian ini yaitu sebagian besar mahasiswa memiliki IPK dengan sangat memuaskan. Sikap kewirausahaan mahasiswa DPTM Prodi S-1 FPTK UPI berada pada kategori tinggi. Sehingga dapat dikatakan mahasiswa DPTM Prodi S-1 FPTK UPI memiliki sikap kewirausahaan yang tinggi serta IPK yang baik.

\section{REFERENSI}

Alma, B. (2009). Kewirausahaan untuk mahasiswa dan umum. Bandung: Alfabeta. 
Ani, R.A. (2013). Model Pengembangan Sikap Kewirausahaan Siswa SMK Negeri SeKabupaten Demak. Jurnal: Universitas Negeri Semarang.

Astamoen, M.P. (2008). Entrepreneurship. Bandung: Alfabeta.

Azwar, S. (1997). Sikap Manusia Teori dan Pengukurannya. Yogyakarta: Pustaka Pelajar.

Dewi, A.N.L. (2015). Pengaruh Sikap Kewirausahaan Terhadap Kemampuan Mengelola Usaha Pada Peserta Program Mahasiswa Wirausaha (PMW UNDIKSHA. Jurnal: Undiksha.

Hasanah, S.A. (2015). Studi Deskriptif Mengenai Sikap Terhadap Kewirausahaan Pada Siswa Kelas XII Sekolah Setingkat SMA di Kecamatan Jatinangor. Jurnal: Universitas Padjajaran.

Jain, V. (2014). 3D Model Of Attitude. Oman: International Journal of Advanced Research in Management and Social Scienses.

Mutmainah, S. (2014). Sikap Kewirausahaan Mahasiswa Jurusan Akuntansi Polines. Jurnal: Polines.

Prawirokusumo, S. (2010). Kewirausahaan dan Managemen Usaha Kecil. Yogyakarta: BPFE.

Sufika, A. (2014). Hubungan Motivasi dan Kompetensi Terhadap Sikap Kewirausahaan. Jurnal: Universitas Sumatera Utara.

Susita, D. (2013). Pengaruh Sikap Kewirausahaan, Kepribadian, Kepuasaan, Kerja Karyawan Kementrian Perindustrian. Jurnal: Universitas Negeri Jakarta. 